\title{
Alumni to the Rescue: Black College Alumni and Their Historical Impact on Alma Mater
}

Received (in revised form): March 25, 2008

\section{Rodney T. Cohen}

is Director of Multicultural Student Affairs at Presbyterian College in South Carolina. He is a graduate of Clark College (GA) and Western Kentucky University and also holds a doctorate in higher education administration from the Peabody College of Vanderbilt University. His interests include alumni giving traditions at historically black colleges, the role of alumni and alumni associations at black colleges, and black alumni affinity groups at majority institutions.

\section{Abstract \\ Throughout their history many black colleges, also referred to as Historically Black Colleges and Universities (HBCUs), have struggled to maintain financial footing. This paper explores the history of alumni involvement in HBCUs and highlights their importance for future success.}

International Journal of Educational Advancement (2008) 8, 25-33. doi:10.1057/ijea.2008.6

\section{Keywords:}

HBCUs, alumni, fund raising

Alumni... must be firmly knit together to rescue Alma Mater.

$$
\text { W. E.B. DuBois }
$$

Throughout their history many black colleges, also referred to as Historically

\footnotetext{
Author's Contact Address:

Rodney T. Cohen

Presbyterian College

Multicultural Student Affairs

PO Box 975

Clinton,

SC 29325, USA

Phone: +1 8648338554

Fax: +1 8648338516

Email: rcohen@presby.edu
}

Black Colleges and Universities (HBCUs), have struggled to maintain financial footing. Recent financial challenges from institutions such as Fisk and Morris Brown continue to illustrate the immediate need for black colleges to establish and maintain strong alumni-giving programs. Although many of the 103 remaining black colleges have struggled at some point, they have, in most cases, found a way to survive. This tradition of "survival" is best described by a particular black college motto: "I'll find a way or make one." This motto is a mantra of sorts for many black colleges and their alumni. Finding a way or making one has helped black colleges and their alumni persist against the odds. Even in the midst of limited funding and questionable spending practices, black college alumni in many cases continue to answer the call and come to the rescue of their alma mater. As early as 1876, not long after emancipation (1863), black college graduates were organizing around alma mater. The purpose of this paper is to look at some of that organization and provide a historical overview of how 
some black college alumni uniquely organized and developed.

Fisk University alumnus W.E.B. DuBois once stated, "the duty of rescuing Fisk rests upon us as graduates (Aptheker, 1973, p. 58)." Since DuBois' charge in 1924, many HBCUs, including Fisk, have experienced a constant struggle in obtaining major gifts and consistent support from the alumni. Film producer Spike Lee portrayed this sentiment in his 1988 film School Daze. Set at a fictitious HBCU, Mission College, Lee explored the controversial topic of alumni giving in a particular scene. The scene featured an exchange between the chairman of the board Cedar Cloud and the college president Harold McPherson (Lee and Jones, 1988, p. 205):

Cedar Cloud: Mission, which began in a church basement, is now spread over two hundred acres. It's grown and the family is concerned ... There is a feeling that the predominately black college for all intents and purposes has outlived its usefulness. Over the years it has been vital to our elevation in this great country, but the need no longer exists in an integrated society.

President McPherson: That's absurd. The need does exist. It exists at Notre Dame, at Yeshiva and Brandeis, at Brigham Young. Tell me what is the difference?

Cedar Cloud: The difference is Catholics alone support the Notre Dames, Jews alone support the Yeshivas, Mormons support Brigham Youngs. Who supports the Black schools? I'll tell you who, the federal government... Mission has produced some of our greatest minds; why don't or why can't we support our own? Why don't Blacks support Tuskegee, Morehouse, Spelman, Howard?

This dialogue, though fictitious, echoes the claim that black college alumni have not consistently supported their alma mater. Contrary to current notions about alumni participation at black colleges, past attempts suggest something different.

\section{Early Black Presence in College}

The establishment of black colleges largely occurred after the emancipation proclamation. All of these institutions were established after 1863 with the exception of Cheney University (1837), Lincoln University (1854), and Wilberforce University (1856). Although the result of emancipation opened doors for the expansion of higher education for blacks, there was an earlier black presence in college. By the 1820s almost 200 years following the founding of Harvard, Alexander Twilight (1823) of Middlebury College, Edward Jones (1826) of Amherst College, and John B. Russworm (1826) of Bowdoin College would earn the distinction of becoming the first blacks in America to receive an undergraduate college degree (Bowles and Decosta, 1971; Hahn, 1998).

By 1860 , only 28 blacks nationally had received a college degree (Bowles and Decosta, 1971). This incremental growth, particularly at black colleges, limited the possibility for any alumni activity of impact. After 1860 the next three decades produced growth and the number of black college graduates would increase gradually. By the turn of the century, approximately 2,400 
blacks had received a college degree. Eighty-three percent of the 2,400 were products of a black college (DuBois, 1903). Prior to 1900 only three black colleges reported more than 100 students enrolled at the college level, Biddle University (Johnson C. Smith University, since 1923), the Lincoln University in Pennsylvania, and Wilberforce University (Johnson, 1938).

By 1915 only 33 private black colleges were offering "college level" instruction of any kind (Anderson, 1988). Of the 12,726 students attending black colleges in 1915 less than 30 percent were enrolled at the college level, whereas 79 percent were enrolled at the elementary and secondary grade level (Anderson, 1988).

It was not until the 1930s that black colleges experienced an increase in "college level" graduates. Although the number of graduates at the college level was small prior to 1900 , the desire to organize and create alumni groups existed early on.

\section{The Alumni Movement}

Early in the history of American higher education, college graduates recognized the need to organize and create alumni clubs, societies, and associations. The first alumni association to gain a charter was in 1821 with the alumni from Williams College (Rowland, 1986). Five years later, in 1826, Princeton alumni organized a similar association, followed by Miami University of Ohio (1832), Amherst College (1842), Brown University (1842), Columbia University (1854), and the University of Michigan (1860). By the late 1800s, over 100 alumni associations had been established nationally.

The nineteenth century ushered in a more formal approach of engaging alumni. As a result, colleges looked to create positions solely dedicated to the management of alumni work. By 1897, the University of Michigan appointed its first alumni secretary. The creation of such positions "brought formal institutional credence to the alumni movement" (Rowland, 1986, p. 375).

\section{Early Alumni at Black Colleges}

Although many black colleges did not produce a substantial number of "college-level" alumni until the 1930s, many of the early graduates did form alumni groups in support of their alma mater. One of the earliest examples is with the graduates of the Lincoln University in Pennsylvania. Lincoln alumni formed an association in 1869 , just one year after the first "collegelevel” class graduated (Bond, 1976). The objective of the newly formed association was to "cooperate with the Trustees and Faculty in advancing all the interests of the University... increasing the number of students... and perpetuate the ties which bind the Alumni to each other and to their Alma Mater (Bond, 1976, p. 331).”

Less than a decade later the alumni of the Lincoln University in Missouri organized their alumni association in 1876 to include all graduates and nongraduates sometimes referred to as "former students" (Savage, 1939). The scope of the organization was to help alumni maintain an interest in the University while also providing financial support. Almost immediately, the Lincoln alumni were active in 
funding scholarships, often times substantial enough to cover a students' tuition and board (Savage, 1939). This early funding initiative played a significant role in increasing the University's enrollment. Oftentimes the alumni efforts in fund raising were noted as being more effective "than having the school itself make the solicitation (Savage, 1939, pp. 139140).”

The Lincoln alumni were not unique when it came to organized, robust alumni activity. By the 1880s and 1890s, alumni south of the MasonDixon began to organize at institutions such as Fisk, Biddle, Alcorn, Morris Brown, and Atlanta University. In 1880 a group of Fisk graduates assembled on campus to establish an association (Allison, 1937). Four years later, by 1884 , the association launched its first publication, known as the Herald, which served as the official voice of Fisk alumni (Richardson, 1980).

In 1885 , less than two decades after the founding of Biddle University, a small but active group of alumni organized. By 1894, Biddle had only 163 graduated students (Parker, 1975). Nonetheless, Biddle alumni provided solid support for their alma mater. During this time, the Biddle alumni association was sponsoring two major events, a Junior Prize Declamation Contest and a Distinguished Alumni Speaker Award (Parker, 1975).

The 1890s introduced a period of growth for some black college alumni groups. During this time new ventures in alumni work were being developed at black colleges. For example, in 1890 Alcorn College in Mississippi established one of the earliest alumni relation operations to be developed at a land-grant college (Posey, 1994). The graduates of Atlanta University would be one of the first black alumni groups to operate alumni clubs away from the college's home city or state (Bacote, 1969). In 1895 they formed The Atlanta University Boston Alumni Association to "promote the welfare of the University and to increase the number of its supporters" in the Boston and New England area (Bacote, 1969, p. 114).

Fisk was one of the first colleges to respond to the trend of students attending college without receiving a diploma. Therefore, in 1890 the NonGraduate Association of Fisk University was established to organize those students who had attended Fisk but not graduated. The Non-Graduate Association also provided a vehicle by which these former students could provide financial support to the University (Richardson, 1980). By 1890 Fisk had over 4,000 students in the nongraduate category (Richardson, 1980).

\section{Alumni Impact on Alma Mater}

In addition to organizing alumni and providing financial support to their alma mater, black alumni associations were also interested in the affairs of the college. As early as the mid-1870s, black college alumni associations challenged policy by submitting petitions regarding faculty hires, board appointments, and racial equality on campus.

For example, in 1875 , the alumni association of Lincoln University in Pennsylvania petitioned for "due diligence" in hiring "representatives of the negro race as teachers" (Bond, 
1976, pp. 333-337). In 1890, the alumni association of Howard University also petitioned their board of trustees to appoint a faculty member of their choosing; in addition, the association agreed to fund the salary (Dyson, 1941). As early as 1910, the alumni of Talladega College made attempts to obtain the authority to select alumni to serve as trustees (Jones and Richardson, 1990).

It was not uncommon, also, for alumni associations to challenge the administration on racial policies common for the times. Hampton Institute's alumni, for example, took an organized approach in 1878 and petitioned their alma mater regarding its racist policies of subordination (Anderson, 1988). In 1926, the alumni of Langston University took a stand and petitioned for a stronger library system and higher faculty salaries, and in 1934 lobbied to institute a program for "Negroes" to pursue graduate work (Patterson, 1979). W.E.B. DuBois in the mid-1920s exclaimed that, "the alumni of Fisk University are and of right ought to be, the ultimate source of authority in the policy and government of this institution (Aptheker, 1973, p. 44)."

Early on, the alumni had a role in financially assisting their alma maters. Unlike some white colleges where donations may have come more readily because of accumulated wealth and access to certain professions, black alumni were typically disadvantaged due to their unique history in America. Bond details this when discussing the financial history of Lincoln (Bond, 1976, p. 464):

One of the most interesting aspects of the financial history of Lincoln
University was the development of a class of alumni sufficiently affluent to contribute to the institution... the early days... developed alumni who were ... so lacking in economic resources that many of them actually remained almoners of the institution long after they had graduated ... As more and more alumni... entered the professions of law and medicine as compared to the first emphasis upon missionary and preaching labors, a number of these men accumulated both means and the willingness to share them with the institution...

As black alumni became more affluent they acted to establish regular giving programs and to provide annual gifts around significant milestones. For many black colleges these milestones revolved around their Founders' or Charter Day celebration. Founders was not only a time to reunite but also served as a critical period to recognize the persistence of their alma mater. Often times the alumni used this day to celebrate the college with a donation or to announce a fund-raising initiative. Colleges such as Talladega and Clark College received regular gifts from alumni on Founders' Day.

On the Founders' Day of 1948 The Talladega College National Alumni Committee on Campus Improvement, pledged to raise $\$ 150,000$ for the college (Jones and Richardson, 1990). Twelve years later in a celebration of their centennial, the alumni pledged to raise $\$ 135,000$ for an endowment earmarked for faculty salaries and student scholarships (Jones and Richardson, 1990).

By the 1950s the Clark College alumni association, for example, was 
leading the annual solicitation efforts for the college around Founders' Day (Mentor, 1958). The National Alumni President often made appeals leading up to Founders' Day. Solicitations provided the opportunity for alumni to give support toward the endowment, scholarships, or unrestricted gifts.

Remembering the struggles of the past, appeals would often call on Clark alumni to remember "the shoulders of every Clarkite... to join hands with the founders of this institution... and give to the best of his ability to the perpetuation of the College (Mentor, 1958, p. 17)."

Early on, the need to be a responsible alumnae or alumnus did not just lie on the shoulders of those early graduates, but also on the students as future alumni. As early as the 1910s, student groups at schools such as Morehouse began to promote the alumni movement in their student publication, The Maroon Tiger, along with making solicitations and contributions toward their own cause.

A noteworthy example was in 1916 when the students of Morehouse College entered into a cooperative effort with alumni to raise money toward a new dormitory. Under the direction of alumnus William E. Griffin, class of 1916, the students raised $\$ 1,000$ within a two-month period toward the campaign (Brawley, 1970).

By the 1920s and 1930s the momentum of giving alumni was rather profitable at selected black colleges. For example, in 1926 the Atlanta University (AU) alumni accounted for approximately one-third of the donations attributed to AU's \$265,000 endowment (Klein, 1929). In a Scholarship Campaign during the early 1930s, Fisk alumni contributed over $\$ 3$ million to the university, with almost $\$ 5,000$ coming from alumni on the Fisk faculty (Allison, 1937).

For the vast majority of black colleges, the chief development and alumni relations operations were the sole responsibility of the college president, the alumni association president, or the association itself. Often considered "their rightful role" in the college's development, the alumni of Talladega made tremendous strides from 1952 to 1962 in their annual gifts as a direct result of the solicitations made by the college's President and the alumni association. During that period the College experienced an increase in annual gifts from $\$ 12,000$ to $\$ 50,000$ (Jones and Richardson, 1990). This momentum resulted in the creation of an Alumni Scholarship Fund, established in 1954. The following year, Talladega alumni were able to award ten freshmen scholarships (Jones and Richardson, 1990).

\section{Alumni Growth and Expansion}

As the student body and alumni base of black colleges grew the need to expand alumni clubs and chapters grew as well. As a result, it "became evident," according to Parker (1975), "that local chapters would be a vital asset in keeping the institution and is needs alive in the hearts of its graduates (p. 46)." Therefore, many black college alumni associations entered the growth phase and established chapters far from their home campus.

As early as 1924 Johnson C. Smith University established its New York 
Chapter under the leadership of a 1916 alumnus (Parker, 1975). Following would be local chapters in Charleston, New Jersey, Washington, DC, and Philadelphia.

North Carolina A\&T State University in Greensboro sowed the seeds for alumni work as early as 1899 when the first graduating class of seven received their bachelor degrees from what was known then as the Agricultural and Mechanical College for the Colored Race (Butler, 1988). Since, they have grown into one of the largest black college alumni associations. In 1964, North Carolina A\&T alumni from New York created a regional structure beginning with the north-east region (Butler, 1988). This regional structure resulted in the creation of four additional regions ranging from Washington State to New Hampshire to Florida. By the 1970s, the North Carolina A\&T Alumni Association had over 75 active chapters nationally with an additional 31 under development (Butler, 1988).

As black college alumni clubs developed nationally, so did their programs. Clubs sponsored various programs such as "College Night," by the Clark Washington Club, as an effort to increase Founders' Day giving among the nation's capital's alumni. Clubs also participated in homecoming activities. In the 1960s the Newman Clark Club, the Atlanta Clark Club, The Chicago Crusaders, and the Future Clarkites sponsored floats with the hopes that every Clark Club would be represented as such in future homecomings (Mentor, 1966).

The black alumni club movement also flourished both at home and abroad. Howard University in the 1960s maintained "constituent clubs" in Bermuda, Guyana, and Jamaica (Howard Magazine, 1968). In addition to the alumni clubs and chapters hosted by black college alumni associations, black colleges also evolved to include alumni organizations specific to the collegiate experience. At Howard, for example, by the 1960s the alumni had organized to form associations around sororities, business majors, medical and pharmacy graduates (Howard Magazine, 1968). The alumni organizations included the Alpha Kappa Alpha, Delta Sigma Theta, and Zeta Phi Beta sororities association as well as the Howard Business Alumni Club, the Medical Alumni Association, and the Pharmacy Alumni Association.

\section{Future of Black College Alumni Associations}

For generations, black colleges have been a major producer of college graduates within the African American community, in some cases accounting for over 80 percent of the degrees granted. Today's marketplace, however, allows for more and more African Americans to consider Traditional White Institutions (TWI). This choice might result in the transfer of potential wealth and alumni support from HBCU to TWI.

The history of blacks in America, in many ways, set the tone for much of the early alumni work experienced at black colleges. Owing to limited access to TWIs and general society, these alumni organized to not only support alma mater but also provide an outlet of community for an educated class.

Today African Americans are afforded much the same opportunities 
as their white counterparts. So instead of attending Howard, they can go to Harvard; instead of Fisk, they can attend Amherst, Smith, or Brown; and instead of Florida A\&M, they can attend Florida State. In addition, many HBCU graduates, at the bachelors level, are choosing TWIs for graduate work, and this experience is opening a new horizon regarding alumni giving.

Black colleges can no longer depend on their alumni as volunteers to carry the load. They will have to make the commitment to cultivate and create innovative measures to garner and keep the attention of its alumni. TWIs within the past $20-30$ years have realized the need for blacks to organize around alma mater and have moved to create African American alumni affinity groups. In addition, they have provided the institutional resources and manpower behind the efforts.

Within the past 30 years black colleges have seen a decline in consistent alumni giving and membership into alumni associations. The need to look to the past is important when understanding how African Americans uniquely organize around alma mater. Unlike the former generations who reached out with an appeal of "give until it hurts," this new breed of alumni will need to see the personal and practical benefit of supporting alma mater.

As many of America's HBCUs continue to face the threat of closure, the issue of alumni support continues to be of major concern. The future of these colleges is inextricably linked to the degree by which they are successful in engaging their alumni in the philanthropic process. The need for HBCUs to enhance their alumni programs is vital to maintaining their important role in American higher education.

\section{References}

Allison, A. (1937), "The growth of organized alumni interest at Fisk University: The challenge of the future," Fisk University News, November.

Anderson, J. (1988), The Education of Blacks in the South, 1860-1935, University of North Carolina Press, Chapel Hill.

Aptheker, H. (ed.) (1973), The Education of Black People, University of Massachusetts Press, Amherst.

Bacote, C. (1969), The Story of Atlanta University: A Century of Service, Princeton University Press, Princeton.

Bond, H.M. (1976), Education for Freedom: A History of Lincoln University, Princeton University Press, Princeton.

Bowles, F. and Decosta, F. (1971), Between Two Worlds: A Profile of Negro Higher Education, McGraw-Hill, New York.

Brawley, B. (1970), History of Morehouse College, McGrath, College Park, MD.

Butler, E. (1988), A History of the National Alumni Association of the North Carolina Agricultural and Technical State University 1891-1984, Ditto Press, College Park.

DuBois, W.E.B. (1903), The Negro Problem, James Platt, New York.

Dyson, W. (1941), Howard University: The Capstone of Negro Education, Howard University, Washington, DC.

Howard University Magazine, January 1968, Vol. X, No. 2.

Johnson, C. (1938), The Negro College Graduate, McGrath Publishing Co., College Park.

Jones, M. and Richardson, J. (1990), Talladega College: The First Century, University of Alabama Press, Tuscaloosa.

Hahn, M. (1998), Alexander Twilight, Vermont's African American Pioneer, The New England Press, Inc., Shelburne, VT.

Klein, A. (1929), Survey of Negro Colleges and Universities, Negro Universities Press, New York.

Lee, S. and Jones, L. (1988), Uplift the Race: The Construction of School Daze, Simon \& Schuster New York.

Parker, I. (1975), The Biddle-Johnson C. Smith University Story, Charlotte Publishing, North Carolina.

Patterson, Z. (1979), Langston University: A History, University of Oklahoma Press, Norman.

Posey, J. (1994), Against Great Odds: The History of Alcorn State University, University of Mississippi Press, Jackson. 
Richardson, J. (1980), A History of Fisk University, 1865-1946, University of Alabama Press, Alabama.

Rowland, W. (ed.) (1986), "Understanding professional roles and program mission," in A.W. Rowland (ed.) Handbook of Institutional Advancement, 2nd edn., Jossey-Bass, San Francisco.
Savage, W. (1939), The History of Lincoln University, Lincoln University, Jefferson City. The Mentor, Winter 1965-1966, "The significance of home coming," Vol. II, No. 1.

Wynn, M.(December 1958), "The founder's day fund," The Mentor, Vol. IV, No. 1. 